\title{
Endometriosis within the inguinal hernia sac
}

\author{
İsmail Zihni (ID), Oktay Karaköse ${ }^{1}$ (ID), Kazım Çağlar Özçelik (ID), Hüseyin Pülat ${ }^{1}($ ID), Hasan Erol Eroğlu (ID), Kemal Kürşat Bozkurt² (ID) \\ ${ }^{1}$ Department of General Surgery, Suleyman Demirel University School of Medicine, Isparta, Turkey \\ 2 Department of Pathology, Suleyman Demirel University School of Medicine, Isparta, Turkey
}

\section{ABSTRACT}

Endometriosis is characterized by the presence of histologically normal endometrial tissue outside the uterine cavity. Endometriotic implants are usually located in the pelvic organs, but they have been described in almost every location of the female body. It may also be present after cesarean section or other gynecological operations. In this study, we reported a rare case of endometriosis located in an indirect inguinal hernia sac.

Keywords: Endometriosis, hernia sac, inguinal canal

Cite this article as: Zihni I, Karaköse O, Özçelik KÇ, Pülat H, Eroğlu HE, Bozkurt KK. Endometriosis within the inguinal hernia sac. Turk J Surg 2020; 36 (1): 113-116.

\section{Corresponding Author}

İsmail Zihni

E-mail: ismailzihni@gmail.com

Received: 15.06 .2015

Accepted: 13.12.2015

Available Online Date: 18.03 .2020

() Copyright 2020 by Turkish Surgical Society Available online at www.turkjsurg.com

DOI: $10.5578 /$ turkjsurg.3247

\section{INTRODUCTION}

Endometriosis is a clinical problem often seen in females of child-bearing age and generally causes dysmenorrhea, dyspareunia, menstrual irregularity and infertility. Although primarily located in the ovaries, the sacro-uterine ligament, rectovaginal septum and pelvic peritoneum, it may also be seen rarely in the vulva, vagina, appendix, stomach, liver, thorax, bladder, umbilicus and the inguinal canal $(1,2)$. In the general population, the incidence of endometriosis is estimated to be 1-8\%. The frequency of endometriosis seen incidentally during any gynaecological intervention in the reproductive years is $15-20 \%$ (3). It is known that endometriosis can be determined during caesarean, hysterectomy, myomectomy, in the episiotomy line following birth, in the trochar location after laparoscopy and especially following pelvic gynaecological operations related to the uterus and endometrium. Its frequency following caesarean has been reported as $0.03-0.4 \%$, which supports mechanical transplantation theory (4-7). The case presented here is of a patient with an uncommonly located endometriosis within an indirect inguinal hernia pouch, which was determined following caesarean operation.

\section{CASE REPORT}

A 31-year-old female patient presented with complaints of pain and swelling in the right inguinal area. The complaints had been ongoing for approximately 1 year, and the pain and swelling increased undertaking strenuous labour. It was learned that the patient had given birth by caesarean section 2 years previously. Physical examination determined a right-sided inguinal hernia. On ultrasonography examination, a cystic structure, $21 \times 12 \mathrm{~mm}$ in size, was seen within the hernia pouch in the right inguinal canal. The decision was made as to operate on the patient, who was informed of the surgical technique and gave a written informed consent. With this diagnosis, the patient was admitted for surgery and the indirect inguinal hernia pouch, together with the $2 \mathrm{~cm}$ cystic mass within, were excised and Lichtenstein herniorrhaphy was applied. No complications occured and the patient was discharged on postoperative day 1. Histopathologic examination of the mass reported it as endometriosis externa (Figures 1 and 2). At the 1-month follow-up gynaecological examination, the patient was determined as normal. 

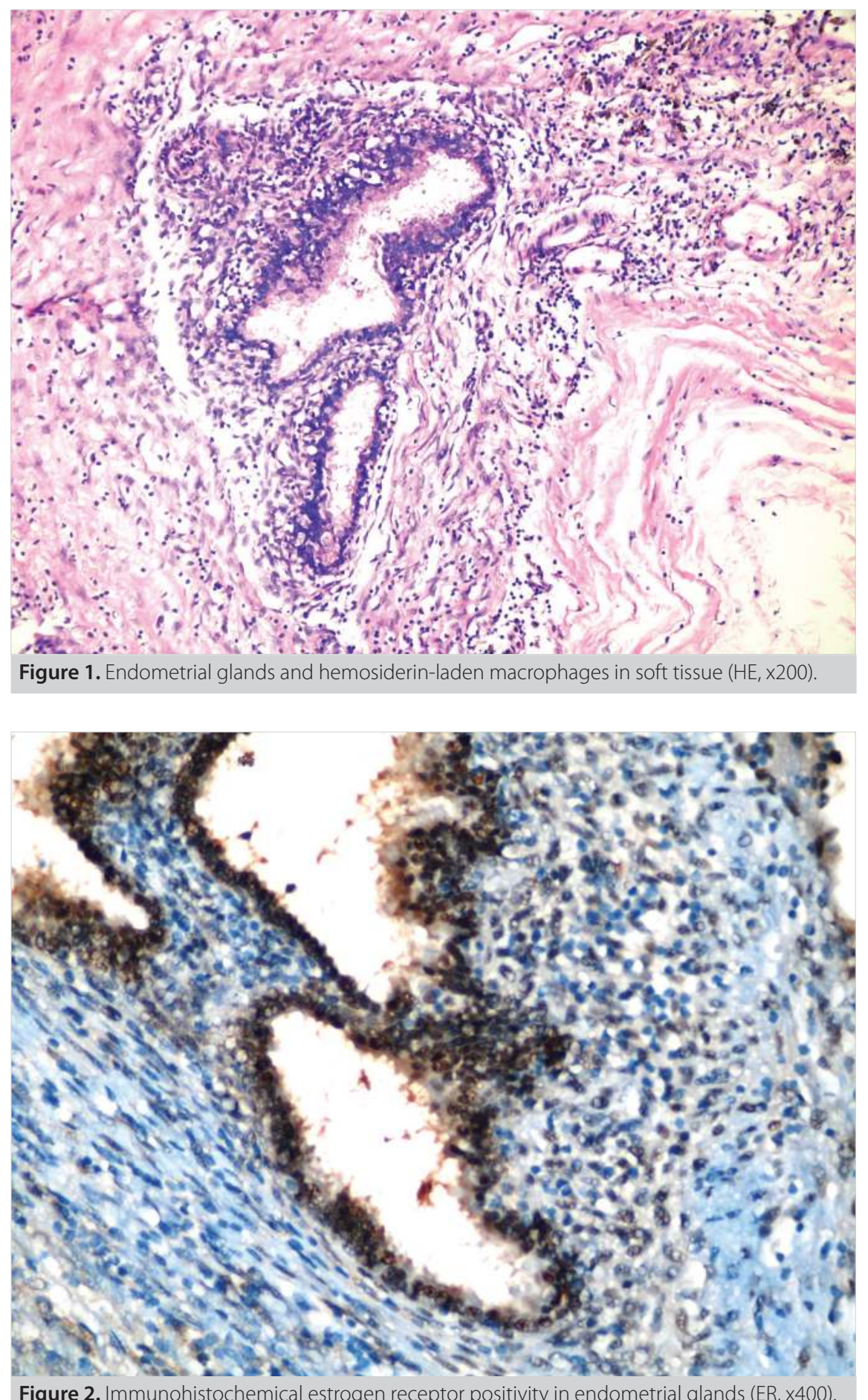

\section{DISCUSSION}

Endometriosis was first described by Von Reclinghausen in 1885 as a functional endometrial tissue outside the uterine cavity (8). Cases of endometriosis outside the pelvis, including the abdominal wall, comprise less than $1 \%$ of all endometriosis cases. The most likely explanation of abdominal wall endometriosis is iatro- genic origin during surgery. The relationship between abdominal wall endometriosis and gynaecological operations was first determined by Aimakhu et al. in 1975 (9). Location in the abdominal wall is determined most frequently below the incision scar, in the umbilicus, within the rectus muscle, in the inguinal canal and rarely in an inguinal hernia pouch (10). Right side is more com- 
mon when endometriosis is within an inguinal hernia pouch. In the case presented here, endometriosis was determined within a right side inguinal hernia pouch. The reason for right side dominance is that intraperitoneal circulation is clockwise and there is the effect of gravity (11).

The most common symptom of endometriosis is menstrual pain, sensitivity, swelling and a (Palpating? perceiving ? a mass) mass. However, these symptoms may not always be evident, as in the case presented here. Uterus surgery, particularly caesarean section operations are a significant risk factor for the development of endometriosis. Similarly, in the current case, who was still in her reproductive period, there was a history of caesarean operation 2 years previously. It has been reported that time elapsing from surgery to clinical presentation of endometriosis may range from 45 days to 20 years (12).

To reduce to a minimum the risk of endometriosis developing from mechanical transportation, it is recommended at the final stage of uterine surgery procedures, that the gloves, needles, suture materials and sponges are changed and removed from the operation area and contact with the wound area should reduced to a minimum. In caesarean operations, before closing the incision line, cleaning with high-flow saline solution is thought to be of benefit (13).

Endometriosis in an inguinal hernia pouch is more often encountered by general surgeons than gynaecologists. As it is a rare occurrence, the diagnosis is extremely difficult. It has been reported in many series that patients with a diagnosis of incarcerated inguinal hernia have been operated on by general surgeons (14). In these rarely seen cases, it may be helpful if there is a patient history of swelling in the inguinal area, especially during menstruation or a history of uterine surgery. However, definitive diagnosis is generally made after histopathological examination (10).

\section{CONCLUSION}

Herniorrhaphy is one of the most frequently performed operations by general surgeons. Although rare within a hernia pouch, endometriosis should be kept in mind and considered.

Informed Consent: Written informed consent was obtained from patient who participated in this case.

Peer-review: Externally peer-reviewed.
Author Contributions: Concept - I.Z., O.K., K.Ç.Ö., H.P.; Design - I.Z., O.K., K.K.B. Supervision - H.E.E.; Materials - K.K.B., K.Ç.Ö.; Data Collection and/or Processing - H.P., K.Ç.Ö., H.E.E., K.K.B.; Analysis and/or Interpretation - I.Z., O.K.; Literature Search - I.Z., O.K., H.P., H.E.E.; Writing Manuscript - I.Z., O.K.; Critical Reviews - I.Z. O.K., H.E.E.

Conflict of Interest: No conflict of interest was declared by the authors.

Financial Disclosure: The authors declared that this study has received no financial support.

\section{REFERENCES}

1. Dwivedi AJ, Agrawal SN, Silva YJ. Abdominal wall endometriomas. Dig Dis Sci 2002:47:456-61. [CrossRef]

2. Blanco RG, Parithivel VS, Shah AK, Gumbs MA, Schein M, Gerst PH. Abdominal wall endometriomas. Am J Surg 2003;185:596-8. [CrossRef]

3. Kinkel K, Frei KA, Balleyguier C, Chapron C. Diagnosis of endometriosis with imaging: a review. Eur Radiol 2006;16:285-98. [CrossRef]

4. Medeiros FD, Cavalcante DI, Medeiros MA, Eleuterio J Jr. Fine-needle aspiration cytology of scar endometriosis: study of seven cases and literature review. Diagn Cytopathol 2011;39:18-21. [CrossRef]

5. Odobasic A, Pasic A, Iljazovic-Latifagic E, Arnautalic L, Odobasic A, Idrisovic $E$, et al. Perineal endometriosiz a case report and review of the literature. Tech Coloproctol 2010;14:25-7. [CrossRef]

6. Raza S, Maqsood R. Siddiqi HA. Abdominal wall endometriosis. J Coll Physicians Surg Pak 2010;20:60-1. [CrossRef]

7. Özgül N, Erten Ö, Türkcan N, Turan T, Köse MF. Endometriosis in cesarean scar: a case report. J Clin Anal Med 2013;4:506-7. [CrossRef]

8. Michowitz M, Baratz M, Stavorovsky M. Endometriosis of the umblicus. Dermatologica 1983;167:326-30. [CrossRef]

9. Douglas C, Rotimi O. Extragenital endometriosis a clinicopathological review of a Glasgow hospital experience with case illustrations. J Obstet Gynaecol 2004;24:804-8. [CrossRef]

10. Kara C, Derici H, Bozdag A, Ermete M. Endometriosis of the abdominal wall: report of three cases. Ulus Cerrahi Derg 2005;21:201-3. [CrossRef]

11. Lam SJ. Pelvic endometriosis with irreductible femoral hernia. BrMed J 1965;1:1126-7. [CrossRef]

12. Candiani GB, Vercellini P, Fedele L, Vendola N, Carinelli S, Scaglione V. Inguinal endometriosis: pathogenetic and clinicalimplications. Obstet Gynecol 1991;78:191-4. [CrossRef]

13. Nominato NS, Prates LF, Lauar I, Morais J, Maia L, Geber S. Caesarean section greatly increases risk of scar endometriosis. Eur J Obstet Gynecel Reprod Biol 2010;152:83-5. [CrossRef]

14. Wasfie T, Gomez E, Seon S, Zado B. Abdominal Wall endometrioma after cesarean section: a preventable complication. Int Surg 2002;87:1757. [CrossRef] 


\section{OLGU SUNUMU-ÖZET}

Turk J Surg 2020;36 (1):113-116

\section{İnguinal herni kesesinde endometriyozis}

İsmail Zihni', Oktay Karaköse', Kazım Çağlar Özçelik', Hüseyin Pülatt', Hasan Erol Eroğlu' ', Kemal Kürşat Bozkurt²

${ }^{1}$ Süleyman Demirel Üniversitesi Tıp Fakültesi, Genel Cerrahi Anabilim Dalı, Isparta, Türkiye

${ }^{2}$ Süleyman Demirel Üniversitesi Tıp Fakültesi, Patoloji Anabilim Dalı, Isparta, Türkiye

\section{ÖZET}

Endometriyozis; histolojik olarak normal endometriyal dokunun, rahim içi boşluğunun dışında bulunmasıdır. Genellikle pelvik organlarda görülmekle birlikte, kadın vücudunda her yerde bulunabilir. Sezaryen ya da diğer jinekolojik operasyonlar sonrasında görülebilmektedir. Biz burada, indirekt inguinal fıtık kesesi içine yerleşmiş, nadir bir endometriyozis olgusunu sunduk.

Anahtar Kelimeler: Endometriyozis, fitık kesesi, inguinal kanal

Doi: $10.5578 /$ turkjsurg.3247 